\title{
妊婦体験ジャケット装着時・非装着時における 降段動作の比較
}

\section{Comparison of Descending Stairs with and without a Jacket Simulating Pregnancy}

$\begin{array}{lllllll}\text { 藤田 } & \text { 智1) } & \text { 江連 } & \text { 志歩1) } & \text { 篠原 } & \text { 卓行 } \\ \text { 1) } & \text { 玉置 } & \text { 広香1) } & \text { 陳 } & \text { 曉菁1) } \\ \text { 新美 } & \text { 英里 }\end{array}$

SATOSHI FUJITA ${ }^{1)}$, SHIHO EZURE ${ }^{1)}$, TAKAYUKi SHINOHARA ${ }^{1)}$, HiROKA TAMAKI ${ }^{1)}$, HSIAOCHING CHEN ${ }^{11}$, ERI NIIMI ${ }^{1)}$, AsUKA MURAMATSU'), JUNJI KATSUHIRA ${ }^{2)}$, SHIGEKO FUJISAWA ${ }^{2)}$

1) Undergraduate Student, International University of Health and Welfare: 2600-1 Kitakanemaru, Otawara-shi, Tochigi 3248501, Japan. TEL +81 287-24-3000

2) Department of Physical Therapy, International University of Health and Welfare

Rigakuryoho Kagaku 20(2): 149-154, 2005. Submitted Dec. 10, 2004. Accepted Feb. 18, 2005.

ABSTRACT: It is said that pregnant women should prevent movements which cause abdominal pressure and excessive joint load. Ascending and descending stairs are movements that cause these kinds of problems. A previous study showed that these kinds of risks in descending stairs were higher than that of ascending stairs. The purpose of this study was to show the effect of pregnancy on lower extremity loads during descending stairs. We compared lower extremity joint moments in six healthy women with and without a jacket simulating pregnancy during descent of two types of stairs. We captured motion data and floor reaction forces using a three-dimensional motion analysis system and four force plates. The results show that knee extension moments were significant larger in descending stairs with the jacket. Also, knee extension moment was affected by the weight of the jacket and trunk bending angle.

Key words: pregnancy, descending stairs, joint moment

要旨 : 妊婦は, 腹圧や過度な関節負担の原因となる動作は避けるべきであるといわれている。階段昇降動作はこのよ うな問題となる動作の一つとされ, 先行研究では階段昇降動作のうち降段動作の方が, 負担が大きいということが示 されている。本研究の目的は, 階段降段動作時において, 妊娠による身体変化が下肢関節負担に与えている影響を明 らかにすることである。対象者は6名の健常成人女性とし, 二種類の階段での降段動作を, 妊婦体験ジャケット装着時 と非装着時において実施した。計測は三次元動作分析装置と床反力計を用いて行い, 関節角度と下肢関節モーメント に着目し, 比較した。結果より, 妊婦体験ジャケットを装着した階段降段時には体重の増加と姿勢の変化により, 膝 関節モーメントが増加することが明らかになった。

キーワード : 妊婦, 階段降段動作, 関節モーメント

1) 国際医療福祉大学＼cjkstart保健学部理学療法学科学部生 : 杤木県大田原市北金丸2600-1（广324-8501) TEL 0287-24-3000

2) 国際医療福祉大学 保健学部理学療法学科

受付日 2004年12月10日 受理日 2005年2月18日 


\section{I.はじめに}

近年国際的に注目されているWomen’s Health Careの中 でも, 理学療法分野では妊産婦の骨盤痛, 腰痛やフィット ネスなどに対するアプローチの研究が多くされている1)。 妊娠による体重増加および重心の変化や生理的変化は, 日常生活動作を行う上で様々な影響を与えている。なか でも, 流早産の原因となる腹圧のかかる動作や関節へ負 担のかかる動作は避けるべきであるといわれており，そ の一つに階段昇降動作が挙げられている2)。

妊婦の動作をバイオメカニクスの面から科学的に検証 している先行研究として, Davids JRらの実際の妊婦を対 象とした平地歩行の研究3)や, 山本らの妊婦体験ジャケッ 卜を用いた研究4)がある。しかし，妊婦の階段昇降動作を バイオメカニクスの面から検証した研究はない。

よって我々は階段昇降動作のうち下肢への負担がより 大きいといわれる降段動作5) 着目し, 妊婦の身体的変化 のうち, 重心位置の変化と体重の増加がどのように階段 降段動作時の下肢負担に影響するか明らかにすることを 目的とした。本研究では下肢関節モーメントを下肢関節 負担の指標とし，三次元動作分析装置，床反力計を用い た動作分析手法により，妊婦体験ジャケットの有無にお ける階段降段動作の違いを下肢負担に着目し，検討した。

\section{II. 対象と方法}

\section{1. 計測方法}

本研究では実際の妊婦を対象とせず，妊婦体験ジャ ケット (KOKEN社製) を用いて研究を行った。妊婦体験 ジャケットは重さ約 $7.2 \mathrm{~kg}$ で, およそ妊娠8～9ケ月目の妊 婦に相当する。対象者は下肢・腰部等に既往歴のない成 人女性6名 (平均年齢 $21.7 \pm 0.8$ 歳, 平均身長 $162.5 \pm 5.0 \mathrm{~cm}$, 平均体重 $52.7 \pm 4.0 \mathrm{~kg}$ ) を対象とした。

計測機器は, 三次元動作分析装置VICON612（VICON MOTION SYSTEMS社製），床反力計（AMTI社製）を用 いた。

対象者の服装は半袖, 短パン, 裸足とし, 図1のように 赤外線反射マーカーを頭頂，左右の肩峰，大転子，膝蓋 骨中央の高さで膝蓋骨の厚さを除く膝関節前後径の中 点, 外果，第5中足骨頭，ダミーの計12個を貼付した。

階段は4段で, 長寿社会対応住宅設計指針の推奨值であ る踏面 $300 \mathrm{~mm}$ 一蹴上160 mm（低い階段）と，踏面が同じ で蹴上を建築基準法の住宅階段上限值とした踏面300 $\mathrm{mm}$ 一蹴上 $230 \mathrm{~mm}$ (高い階段) のものとし, 床反力計の 上に設置した。

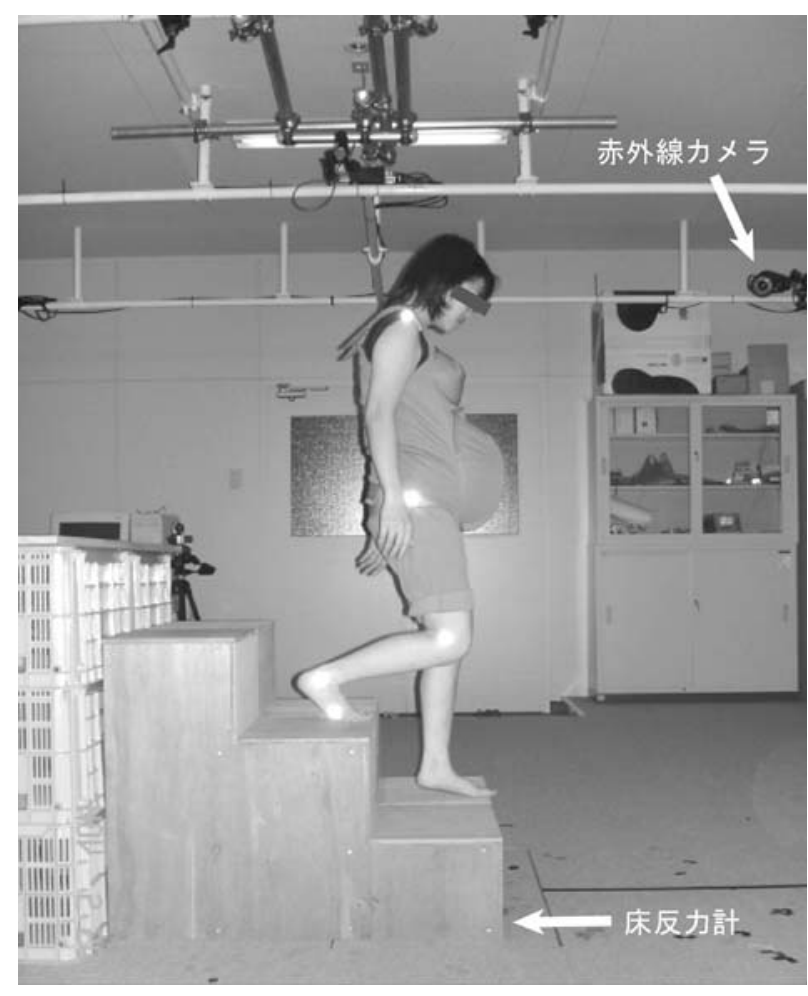

図1 測定風景

\section{2. 計測条件}

妊婦体験ジャケットの有無，階段の高低の4条件にて 各々 2回ずつ降段動作を行い，踏み出しは全て左脚から とした。「二つの階段の中央は踏まないように」とだけ指 示し，階段降段動作のスピード，視線の位置については, 指示は出さずに，普段の動作に近いものとした。各被験 者は2日に渡り測定を行い, 初回は(1)低い階段・ジャケッ 卜無し(2)低い階段・ジャケットあり，2回目は(3)高い階 段・ジャケット無し(4)高い階段・ジャケットありで測定 した。また, 各条件において, ジャケットの重さや階段 に慣れるまで練習を行った。

\section{3. 統計処理}

解析は，左右の合成床反力，関節角度（股関節，膝関 節，足関節，体幹），関節モーメント（股関節，膝関節， 足関節）のデータより，対応のあるt検定を用いて統計処 理を行い，危険率5\%未満を有意とした。また，関節モー メントは，被験者の身長（m）と体重（kg）の積で除し て正規化した。また, 通常体格差による筋力の違いを考 慮するため，全体重と身長の積で関節モーメントを正規 化するが，ジャケット装着の際はジャケットの重量が身 体に加わるのみで筋力は変化しないため, ジャケットの 


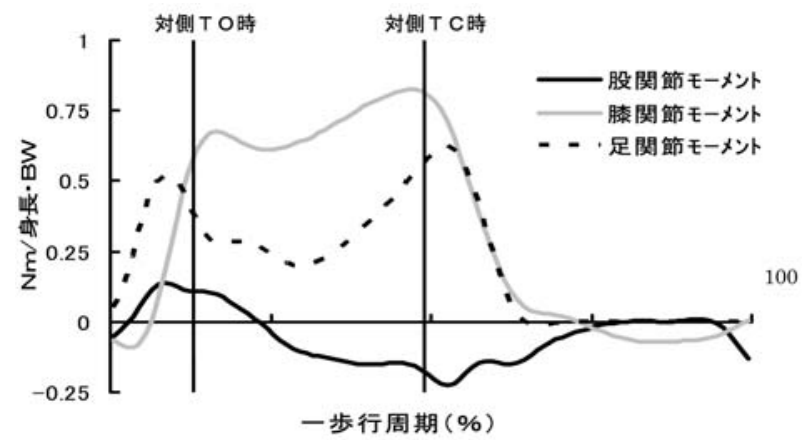

図2 後段対側TP, TC時

重さ (約 $7.2 \mathrm{~kg}$ ) は体重に含めず, 同様な方法で正規化した。

\section{III. 結 果}

図2に階段降段時の右足接地を開始とした一歩行周期 における右下肢関節モーメントの代表例を示す。右下肢 三関節の波形は，左足指離地時（以下，対側TO時）と左 足指接地時（以下，対側TC時）に増加していた。この傾
向は全ての被験者に共通してみられるため, これら二つ の時期の值を抽出して比較検討することとした。各階段 降段時においてジャケット有無での関節角度（体幹, 股 関節，膝関節，足関節），下肢関節モーメントを比較し た。関節角度の計算は静止立位時の関節角度を0度として 行った。

対側TO・TC時の結果については，表1，2に示す。体 幹後屈角度は, ジャケットを装着すると両階段の対側 $\mathrm{TO}$ ・TC時ともに有意に増加した。

対側TO時では, ジャケット装着による変化として低い 階段で膝関節伸展モーメント, 高い階段では股関節伸展 モーメントが有意に増加した。

対側TC時においては, 各階段とも膝関節伸展モーメン トが増加し, 低い階段においてのみ足関節伸展モーメン トが有意に増加した。

\section{IV. 考 察}

スティックピクチャーを参考に作成した模式図を用い て考察を進めていく。関節モーメントに影響を与える要 因としては，床反力の大きさ，および関節軸から床反力

表1 低い階段の下肢関節角度およびモーメント

a）下肢関節角度

\begin{tabular}{llrrc}
\hline & & ジャケット無し & ジャケット有り & 有意性 \\
\hline 対側 TO & 体幹前後屈角度 & $5.34 \pm 2.47$ & $8.01 \pm 2.52$ & $\mathrm{p}<0.05$ \\
& 股関節屈伸角度 & $12.45 \pm 5.01$ & $16.38 \pm 4.34$ & $\mathrm{p}<0.05$ \\
& 膝関節屈伸角度 & $24.79 \pm 7.53$ & $29.46 \pm 5.03$ & $\mathrm{p}<0.05$ \\
& 足関節底背屈角度 & $-6.27 \pm 6.77$ & $-5.44 \pm 4.70$ & $\mathrm{n} . \mathrm{s}$ \\
\hline 対側 TC & 体幹前後屈角度 & $5.75 \pm 2.20$ & $8.71 \pm 2.52$ & $\mathrm{p}<0.05$ \\
& 股関節屈伸角度 & $5.77 \pm 5.52$ & $8.80 \pm 5.69$ & $\mathrm{p}<0.05$ \\
& 膝関節屈伸角度 & $50.43 \pm 7.90$ & $52.91 \pm 7.99$ & $\mathrm{p}<0.05$ \\
& 足関節底背屈角度 & $16.34 \pm 5.44$ & $16.56 \pm 4.89$ & $\mathrm{n} . \mathrm{s}$ \\
\hline
\end{tabular}

単位 $\left.{ }^{\circ}\right]$, (平均土標準偏差), n.s: not significant

b) 下肢関節モーメント

\begin{tabular}{llccc}
\hline & & ジャケット無し & ジャケット有り & 有意性 \\
\hline 対側 TO & 股関節屈伸モーメント & $0.10 \pm 0.10$ & $0.14 \pm 0.12$ & $\mathrm{n} . \mathrm{s}$ \\
& 膝関節屈伸モーメント & $0.37 \pm 0.22$ & $0.61 \pm 0.22$ & $\mathrm{p}<0.05$ \\
& 足関節底背屈モーメント & $0.56 \pm 0.15$ & $0.47 \pm 0.20$ & $\mathrm{n} . \mathrm{s}$ \\
\hline \multirow{2}{*}{ 対側 TC } & 股関節屈伸モーメント & $-0.21 \pm 0.06$ & $-0.19 \pm 0.08$ & $\mathrm{n} . \mathrm{s}$ \\
& 膝関節屈伸モーメント & $0.62 \pm 0.15$ & $0.75 \pm 0.17$ & $\mathrm{p}<0.05$ \\
& 足関節底背屈モーメント & $0.52 \pm 0.09$ & $0.64 \pm 0.07$ & $\mathrm{p}<0.05$ \\
\hline
\end{tabular}

単位 $[\mathrm{Nm} /$ 身長 $\cdot \mathrm{BW}]$, (平均土標準偏差), n.s:not significant 
表2＼cjkstart高い階段の下肢関節角度およびモーメント

a）下肢関節角度

\begin{tabular}{llccc}
\hline & & ジャケット無し & ジャケット有り & 有意性 \\
\hline 対側 TO & 体幹前後屈角度 & $4.81 \pm 3.15$ & $6.37 \pm 2.91$ & $\mathrm{p}<0.05$ \\
& 股関節屈伸角度 & $14.83 \pm 3.02$ & $14.96 \pm 4.07$ & $\mathrm{n} . \mathrm{s}$ \\
& 膝関節屈伸角度 & $29.95 \pm 5.52$ & $28.43 \pm 6.43$ & $\mathrm{n} . \mathrm{s}$ \\
& 足関節底背屈角度 & $-4.14 \pm 6.01$ & $-6.29 \pm 7.45$ & $\mathrm{p}<0.05$ \\
\hline 対側 TC & 体幹前後屈角度 & $6.02 \pm 2.43$ & $7.30 \pm 3.17$ & $\mathrm{p}<0.05$ \\
& 股関節屈伸角度 & $13.00 \pm 3.77$ & $14.97 \pm 4.83$ & $\mathrm{p}<0.05$ \\
& 膝関節屈伸角度 & $69.97 \pm 5.36$ & $72.68 \pm 5.57$ & $\mathrm{p}<0.05$ \\
& 足関節底背屈角度 & $15.27 \pm 3.81$ & $14.90 \pm 4.04$ & $\mathrm{n} . \mathrm{s}$ \\
\hline
\end{tabular}

単位 $\left[^{\circ}\right]$, (平均土標準偏差), n.s: not significant

b）下肢関節モーメント

\begin{tabular}{llccc}
\hline & & ジャケット無し & ジャケット有り & 有意性 \\
\hline 対側 TO & 股関節屈伸モーメント & $0.21 \pm 0.06$ & $0.28 \pm 0.09$ & $\mathrm{p}<0.05$ \\
& 膝関節屈伸モーメント & $0.44 \pm 0.19$ & $0.42 \pm 0.28$ & $\mathrm{n} . \mathrm{s}$ \\
& 足関節底背屈モーメント & $0.68 \pm 0.18$ & $0.82 \pm 0.23$ & $\mathrm{n} . \mathrm{s}$ \\
\hline 対側 TC & 股関節屈伸モーメント & $-0.14 \pm 0.05$ & $-0.14 \pm 0.08$ & $\mathrm{n} . \mathrm{s}$ \\
& 膝関節屈伸モーメント & $0.74 \pm 0.14$ & $0.82 \pm 0.19$ & $\mathrm{p}<0.05$ \\
& 足関節底背屈モーメント & $0.55 \pm 0.11$ & $0.59 \pm 0.14$ & $\mathrm{n} . \mathrm{s}$ \\
\hline
\end{tabular}

単位 $[\mathrm{Nm} /$ 身長 $\cdot \mathrm{BW}]$, (平均土標準偏差), n.s: not significant

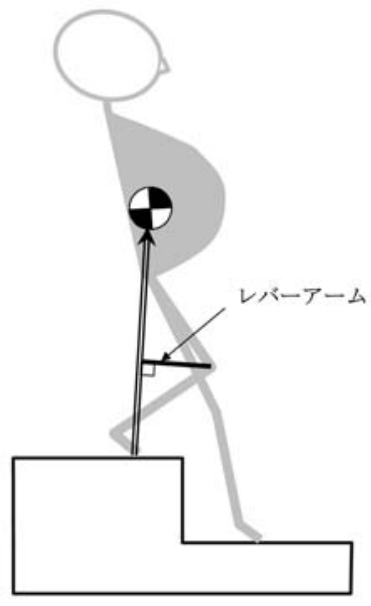

図3 レバーアーム（階段降段動作の一例より）

ベクトルへの垂線の距離（以下レバーアーム, 眓3参照） が関与する。今回関節モーメントに着目し，低い階段と 高い階段において，次の1）～4）に分けて考察を進めて いく。
1. 低い階段一対側TO・TC時に共通してみられる点（図4 参照)

対側TO・TC時ともに，ジャケット装着により体幹後 屈角度，膝・股関節屈曲角度，膝関節伸展モーメントの 増加がみられた。被験者はジャケットを装着することで, 重心位置が前方に変位するため, 体幹後屈角度を増加さ せ支持基底面の中で重心を安定させることが必要とな る。この体幹後屈角度の増加により, 床反力ベクトルも 後方へ向かう。その結果，膝関節からのレバーアームが 増大し, 膝関節伸展モーメントが増加したと考えられる。 特に対側TC時に膝関節伸展モーメントが増加する原因 は，体幹後屈角度の増加によって踏面から足部が離れ， 膝関節屈曲角度を増加させ，その距離を補ったためと考 えられる。

2. 低い階段一対側TC時にみられる点（図4参照）

対側TC時における足関節の役割は，足関節底屈筋を遠 心性収縮させることにより，対側下肢が下段に安定して 接地できるようにすることである。

ジャケット装着により, 足関節底屈モーメントの増加 がみられたが，足関節背屈角度の増加は認められず，レ 


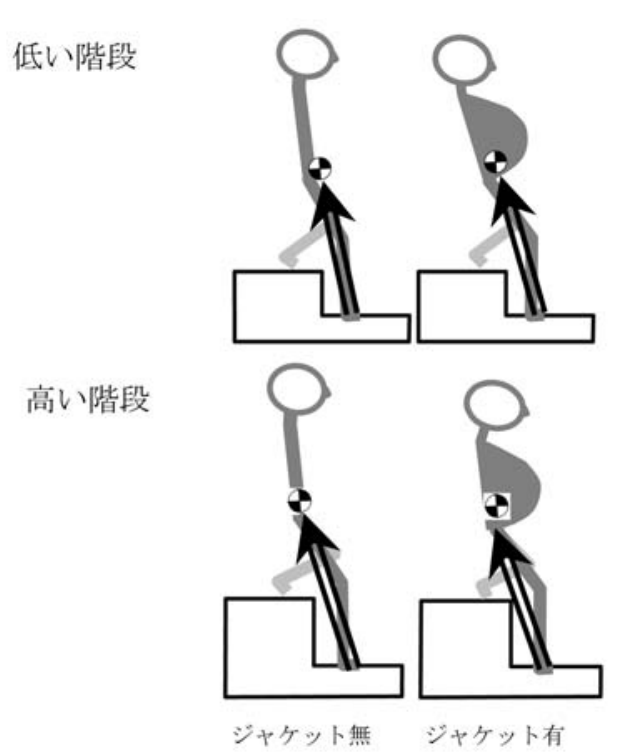

対側 T O 時
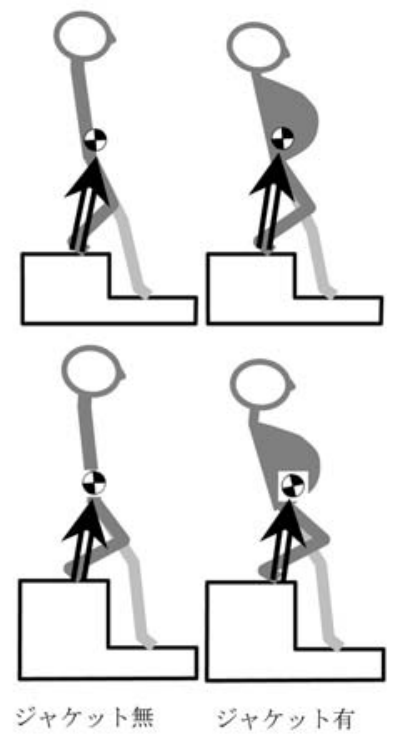

対側 T C 時

図4 各階段におけるスティックピクチャー

バーアームは変化しなかったため, ジャケット装着によ る体重の増加が足関節底屈モーメントの増加をもたらし たと考えられる。また, 体重が増加することによって, 対側下肢を下段に安定して接地させるために足関節底屈 モーメントの役割が大きく必要となったと考えられる。

3. 高い階段一対側TO時にみられる点（図4参照）

ジャケット装着により, 体幹後屈角度の増加, 股関節 伸展モーメントの増加がみられる。蹴上が高くなると必 然的に身体重心を下方に降万す高さも高くなるため，下 肢全体の負担は大きくなる。ジャケット装着時には体重 が増加するため, 下肢負担はさらに大きくなる。通常階 段降段動作では膝関節伸展, 足関節底屈のモーメントが 大きく, 股関節モーメントは小さくなる5)。しかし、ジャ ケットを装着して高い階段を降段する場合には, 膝関節 伸展モーメントと足関節底屈モーメントを軽減させるた めに股関節伸展モーメントが増加したと考えられる。

4. 高い階段一対側TC時にみられる点（図4参照）

ジャケット装着により, 膝関節伸展モーメントが増加 した原因は，1）と同様の理由から，体幹後屈角度の増 加, 膝関節屈曲角度の増加によるレバーアームの増大が 考えられる。

表1-a）と表2-a）にてジャケット装着した際の対側TC
時における体幹前後屈角度を比較すると, 体幹後屈角度 は高い階段よりも低い階段で増加していた。高い階段に おいても低い階段同様に大きく体幹を後屈させると重心 は後方へ移動し, 床反力ベクトルが後方へ傾いて膝関節 からのレバーアームがより増大寸ることになるため，膝 関節への負担はさらに増大寸る。よって膝関節への負担 を軽減させるために, 被験者は低い階段と比べ高い階段 で体幹後屈角度を減少させたと考えられる。

また，低い階段の場合，ジャケット装着により足関節 底屈モーメントの増加がみられるが, 高い階段では足関 節底屈モーメントの増加はみられなかった。これは, 膝 関節屈曲角度が, 低い階段の時と比へ, 約20度増加して いるため, 下腿三頭筋のうちの二関節筋である, 腓腹筋 の筋出力低下が原因であると考えられる。腓腹筋活動は 膝関節を屈曲させた肢位では, 70\%減少する5) という報告 がなされており, ジャケットを装着しても, 高い階段で は足関節底屈モーメントに有意な変化はみられなかった と考えられる。

\section{V. まとめ}

本研究では実際の妊婦を対象とした研究を行うための 基礎データとして妊婦体験ジャケットを使用した研究を 行ったが1）〜4）よりジャケット装着により，体幹後屈 
角度の増加が，下肢関節に大きな影響を与えることがわ かる。今回は, 体幹角度, 下肢関節に着目し検討したが, 今後は実際の妊婦を対象とするとともに，骨盤・腰部等 へかかる負担も含め，バイオメカニクスの面から総合的 に検討する必要があると考える。

謝 辞 本研究を進めるにあたり，多大なるご協力をい ただいた国際医療福祉大学看護学科の江幡芳枝教授, 大 田原赤十字病院看護部長河野順子様, および産科外来の 皆様に, 心より厚く御礼申し上げます。

\section{引用文献}

1) 小倉秀子: Women’s Health Care と理学療法. 理学療法, 2004,
21(6): 795-798.

2) 松本清一 : 系統看護学講座専門25 母性看護学 2 母性看護 学各論2, 第9版. 医学書院, 東京, 2002, pp146-147.

3) Foti T, Davids JR, Bagley A: A biomechanical analysis of gait during pregnancy. J Bone Joint Surg (Am), 2000, 82A(5): 625-632.

4) 山本祐子, 遠藤美香, 菅原亜子・他：ヒールの高さが妊婦歩 行に与える影響. 理学療法科学, 2004, 19(2): 107-110.

5) 勝平純司, 山本澄子, 関川伸哉・他 : 階段およびスロープ昇 降時の関節モーメントの分析. バイオメカニズム，2004, 17: 99-107.

6) Perry J, Easterday CS, Antonelli DJ: Surface versus intramuscular electrodes for electromyography for superficial and deep muscles. Phys Ther, 1981, 61: 6-15. 